（色材，55[6] 399-412. 1982)

\title{
塗膜物性に及ぼす水の影響
}

\section{1.は しがき}

塗料は常温・常湿下で塗装され, 塗膜となって使用さ れる。したがって, 塗膜は形成・劣化の過程を通じて, その一生は水と密接な関係があり, 塗膜の性質を考える ときには，水の影響を無視することはできない。通常塗 膜と水の関係は白化，ピンホール，クレター，色分れな

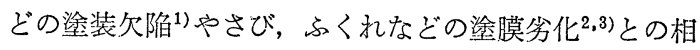
関性といら観点から検討されている。

ポリビニルアルコールのよらな吸水性に富むポリマー を除けば，普通の合成ポリマーの吸水率は表-1 に示す ように 0.1 5\% 程度である。それでポリマーの物性は 湿度に余り影響されないか，西るいは影響されても温度 効果に比べると，小さいと考光がちである。しかし，ポ リマーの物性に及ぼす水の影響は大きく, 水分によりガ ラス転移温度の低下することが知られている。

表-1 ポリマーの吸水率

\begin{tabular}{|c|c|}
\hline $\begin{array}{c}\text { 吸水率 } \\
(\%)\end{array}$ & ポリマ \\
\hline 5 以上 & ポリビニルアルコール \\
\hline $1 \sim 5$ & $\begin{array}{l}\text { 七ルロースェステル，ポリ酢酸ビニル， ポ } \\
\text { リビニルブチラール，ナイロン }\end{array}$ \\
\hline $0.1 \sim 1$ & $\begin{array}{l}\text { ポリ塩化ビニル, ポリスチレン系コーポリ } \\
\text { マー, ポリメチルメタクリレート, ポリカ } \\
\text { ーボネート, ポリェチレンテレフタレー } \\
\text { ト, メラミン樹脂, ウレタン樹脂 }\end{array}$ \\
\hline 0.1 以下 & $\begin{array}{l}\text { ポリェチレン, ポリプロピレン, テフロ } \\
\text { ン, ポリ塩化ビニリデン, ポリスチレン }\end{array}$ \\
\hline
\end{tabular}

昭和 56.10.15 受理

The Effect of Water on the Physical Properties of Coating Films

Kozo Sato

* (株) 寺岡製作所佐野工場

栃木県佐野市栄町 12-2（广327）
佐 藤 弘 三*

塗膜物性の経時変化を調バることを目的として, 塗膜 を沸騰水中で一定時間処理した後, 光沢, 耐衝撃性, エ リクセン仵びなどを評価し，これを二次物性と称してい る。塗膜を熱水で処理すると，叙膜中の低分子量プレポ リマーや未反応の橋かけ剂の溶出, 分子鎖の切断などが 起こり, 熱水処理後の塗膜物性は変化する。

藤田ら ${ }^{4)}$ は固体ポリーの力学的性質が温度に敏感で あると同時に，湿度に対しても同様な挙動を示すことを 明らかにし，このような水の浸透膨潤によって起こるポ リマーの分子構造の緩和機構について, 次のような考觉 を示唆した。

(1) ポリマー構造中の水素結合のような二次結合の切 断あるいはエステル結合のような一次結合の加水分解に よる切断を伴う化学的劣化。

(2) ポリマー構造中に存在する親水性官能基による水

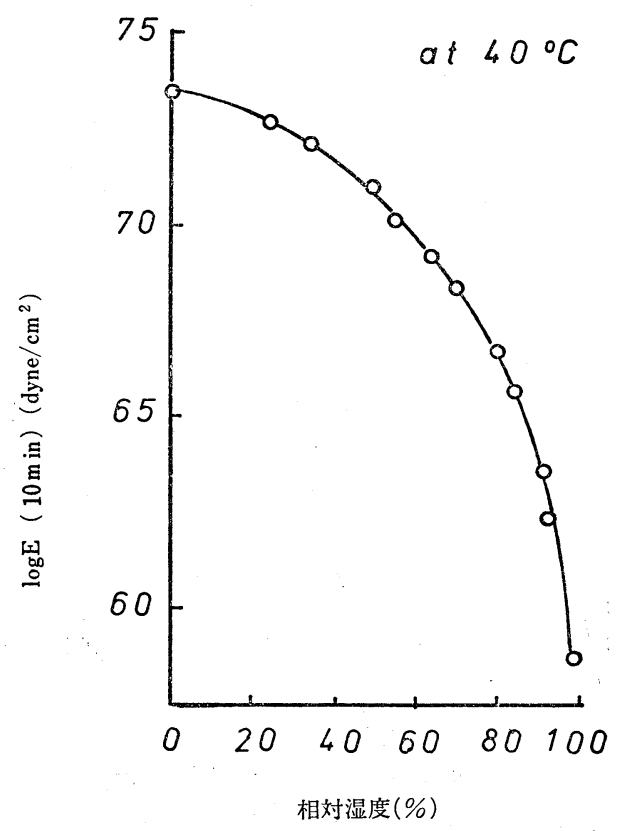

図-1 ポリ酢酸ビニルの弾性率と湿度の関係 


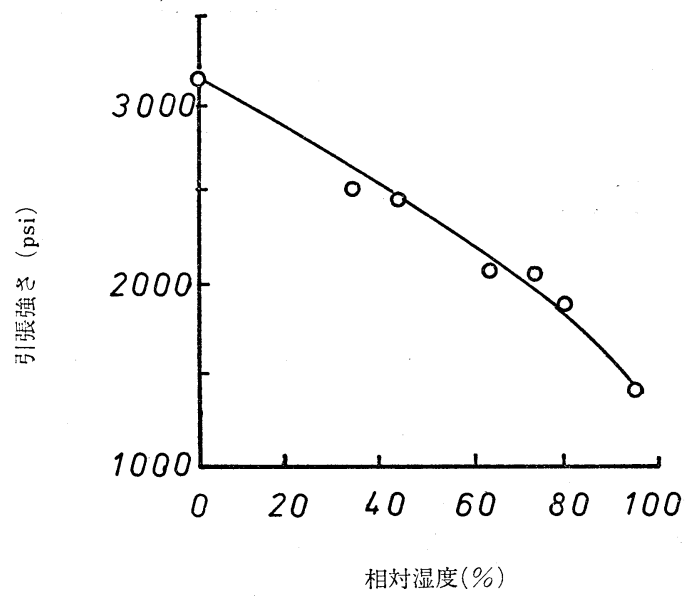

図-2 長油性アルキド樹脂塗膜の引張強さに及ぼす 湿度の影響

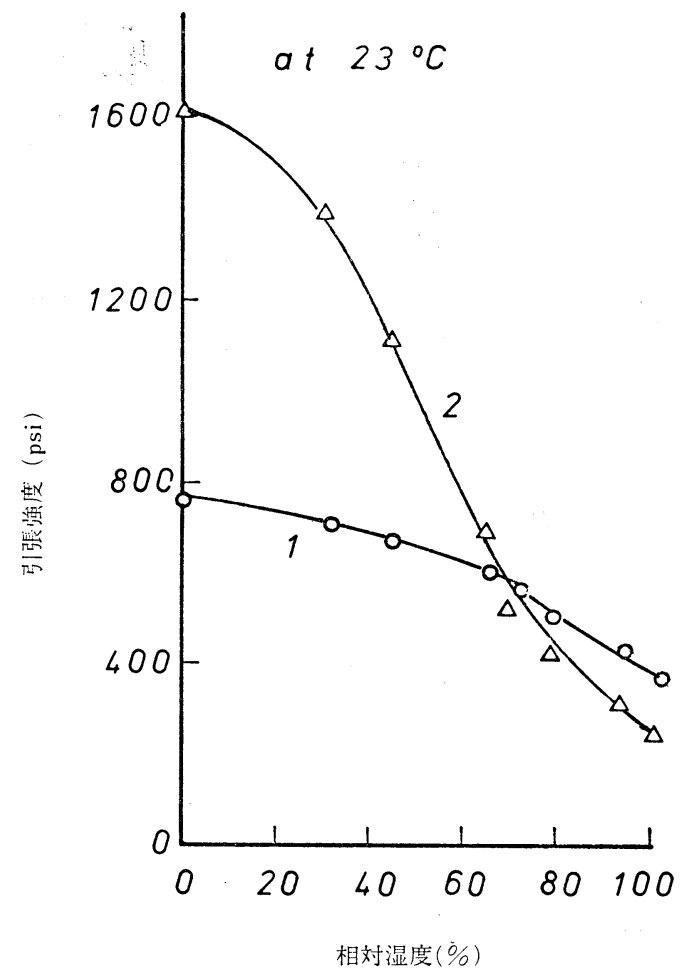

図-3 エマルジョン塗膜の引張強さに及ぼす湿度の影響

$1:$ ポリ酢酸ビニル

$2:$ 酢酸ビニル/2-エチルヘキシルアクリレートュー ポリマー

分子の吸着と水の拡散に伴う膨潤による可塑化效果。

実際には，ポリマーが水と接触する際には，この二つ のメカニズムは重畳的に作用しており，分子鎖の切断あ るいは可塑化効果という択一的メカニズムによるとは限

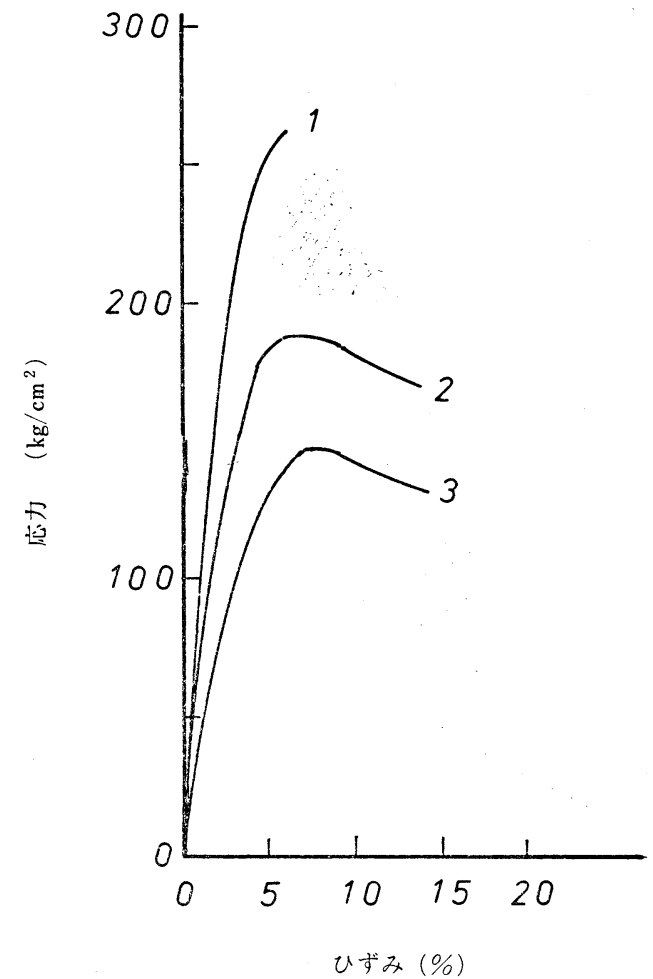

図-4 アクリル・メラミン樹脂塗膜の応力ーひずみ 特性に及ぼす水中浸漬の影響

$$
\begin{aligned}
& 1: \text { 浸漬前 } \\
& 2: 90^{\circ} \mathrm{C}, 4 \mathrm{hrs} \text { 浸漬 } \\
& 3: 90^{\circ} \mathrm{C}, 16 \mathrm{hrs} \text { 浸漬 }
\end{aligned}
$$

らない。本文では塗膜の力学的性質および内部応力に及 洔す水の影響について述べる。

\section{2. 塗膜の機械的性質と水}

一般に塗膜中に浸透・拡散した水分子は可塑剂的に挙 動するので，吸湿により塗膜の弾性率や引張強さは低下 し，破壊伸びは増加する。図一1 はポリ酢酸ビニルの弾 性率に及涪す湿度の影響を示し5)，60\% RH になると弾 性率が急激に低下寸ることが認められる。この場合，ポ リマーの吸湿量は $70 \% \mathrm{RH}$ でも $2 \%$ に達せず， $100 \%$ $\mathrm{RH}$ でも $5 \%$ 強であり，この程度の吸湿により弾性率は 急減する。図-2 $2^{6)}$ と図- $3^{7)}$ は塗膜の引張強さと湿度の関 係を示し，いずれも湿度の堌加により引張強さは低下す る。

図-4 は熱水中に浸漬したアクリル・メラミン樹脂塗 膜の応力ーひずみ特性を示し ${ }^{8)}$, 塗膜は破壊強さが低下し て破壊伸びを增加し，この場合には塗膜の化学的劣化 と吸着水分子による可塑化方゙生じていると考光られる。 このような熱水処理をした塗膜を再乾燥すると, 熱水処 


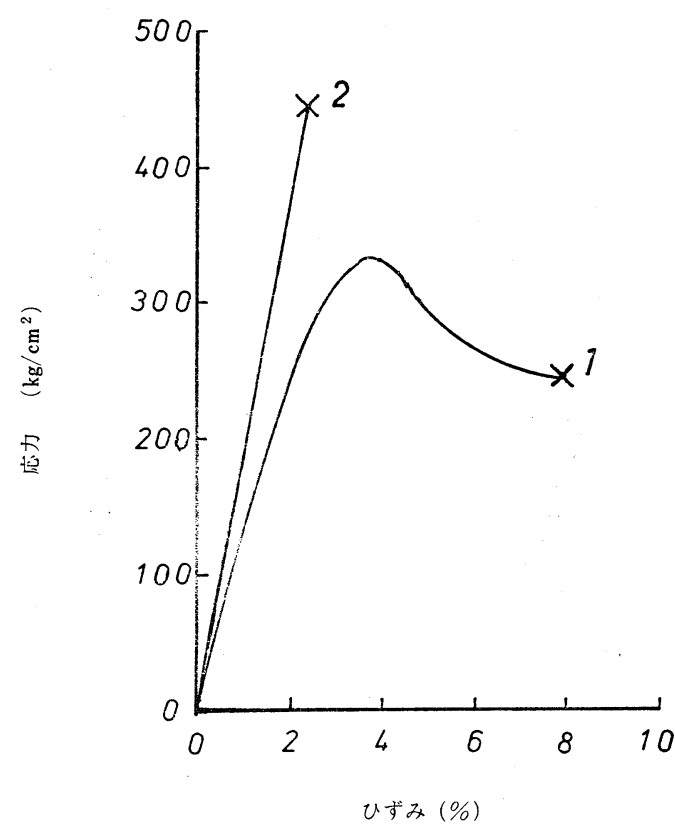

図-5 アクリル・メラミン樹脂叙膜の応力ーひずみ 特性に及济す沸水処理の影響

$1:$ 沸水浸漬前

$2:$ 沸水処理 $2 \mathrm{hrs}$ 後再乾燥

理前後で塗膜の物性は著しく変化することがある。図-5 はアクリル・メラミン樹脂塗膜を沸騰水で処理したとき の前後に和汀る応力ーひずみ特性を示し, 沸騰水処理に より弾性率と引張強さは増加するが, 破壊伸びは減少し てもろくなるき。

\section{3. 塗膜の粘弾性と水}

図-6 はセルロース系塗膜の吸湿による 粘弾性の変化 を示し ${ }^{10)}$, 吸湿によりせ九断弹性率 $G$ は低下し, 対数減 衰率入を增加する。図-7 は同じセルロース系塗膜の 25 $\sim 65^{\circ} \mathrm{C}$ の温度範团飞和外る 粘弾性変化を示し ${ }^{11)}$, 図-6 と図-7をくらべると，次のことがわかる。すなわら， 二酢酸セルロース $(2 \mathrm{AC})$ とニトロセルロース $(\mathrm{NC})$ は 40 50\% RH に入 の極大が認められ, 粘弾性曲線の形は 湿度効果も温度効果とよく似ている。また, 而水性が良 く, 吸湿性の小さいベンジルセルロース (BC) と三酢酸 セルロース (3AC) 以外のセルロースは, 温度と湿度の 相似性が認められ, セルロース系塗膜では常温・常湿下 で乾燥試料の $\beta$ 転移の温度分散に相当する吸湿転移の生 ごていることがわかる。セルロース系塗膜が室温条件下 で剛い割にもろくない原因の一つは，このような吸湿転 移が生じているためであろう。しかし, 吸湿転移と温度 転移の内容は同じでなく, 吸湿転移は分子鎖間の水素結
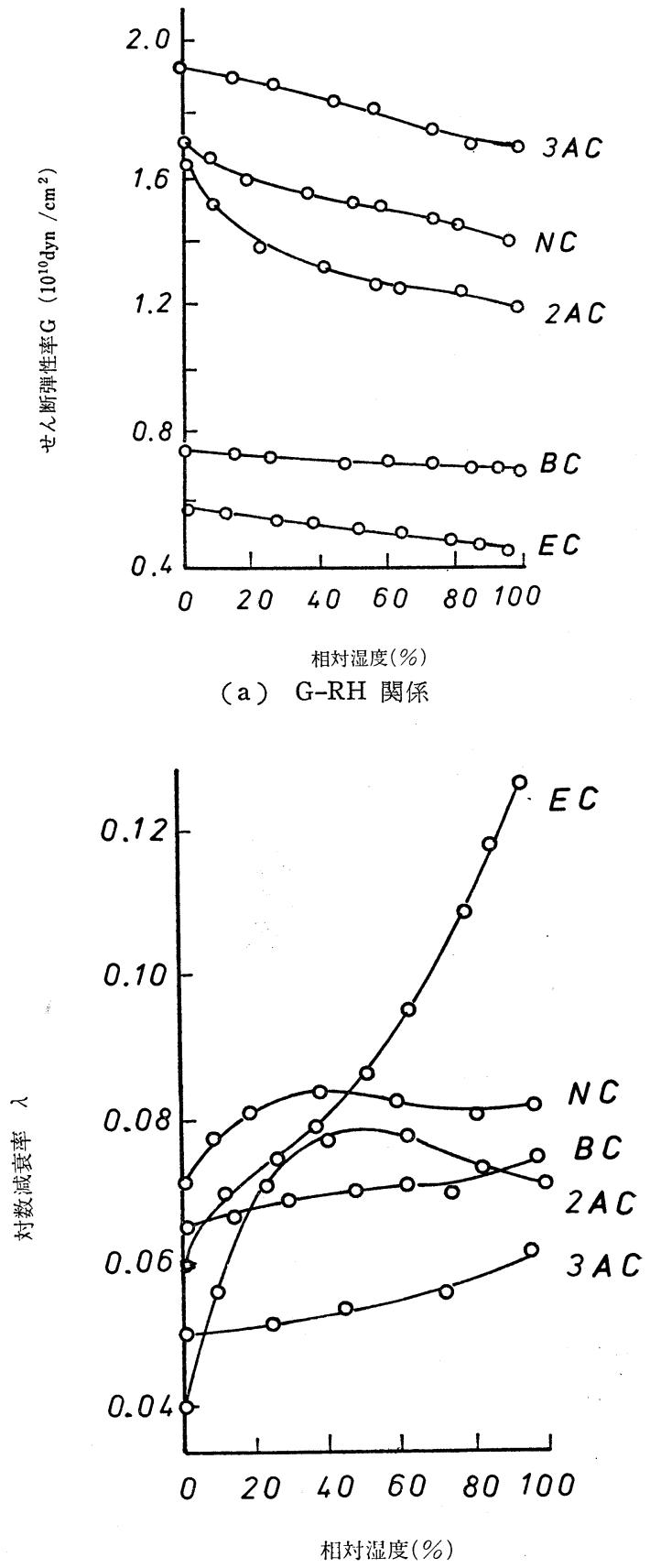

(b) $\lambda-\mathrm{RH}$ 関係

図-6 セルロース系塗膜のせん断弹性率 $G$ 之対数減衰率 $\lambda$ に及注す湿度の影響（図中の記号は図-7 む同じ）
$\mathrm{BC}$ : ベンジルセルロース
$\mathrm{EC}:$ エチルセルロース
$\mathrm{NC}:$ ニトロセルロース $2 \mathrm{AC}:$ 二酢酸セルロース $3 \mathrm{AC}:$ 三酢酸セルロース 

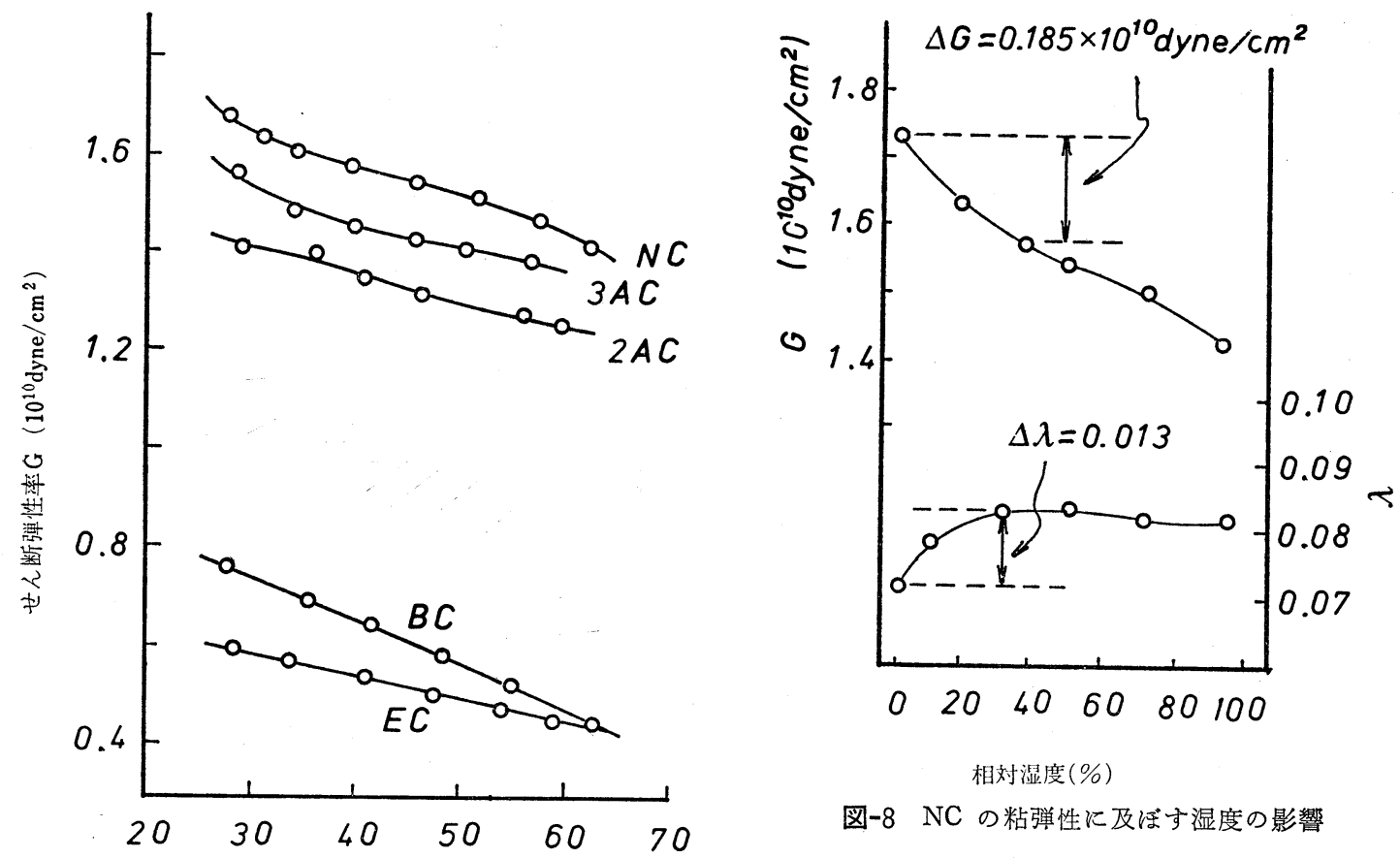

相対湿度 $(\%)$

図-8 NC の粘弾性に及ぼす湿度の影響

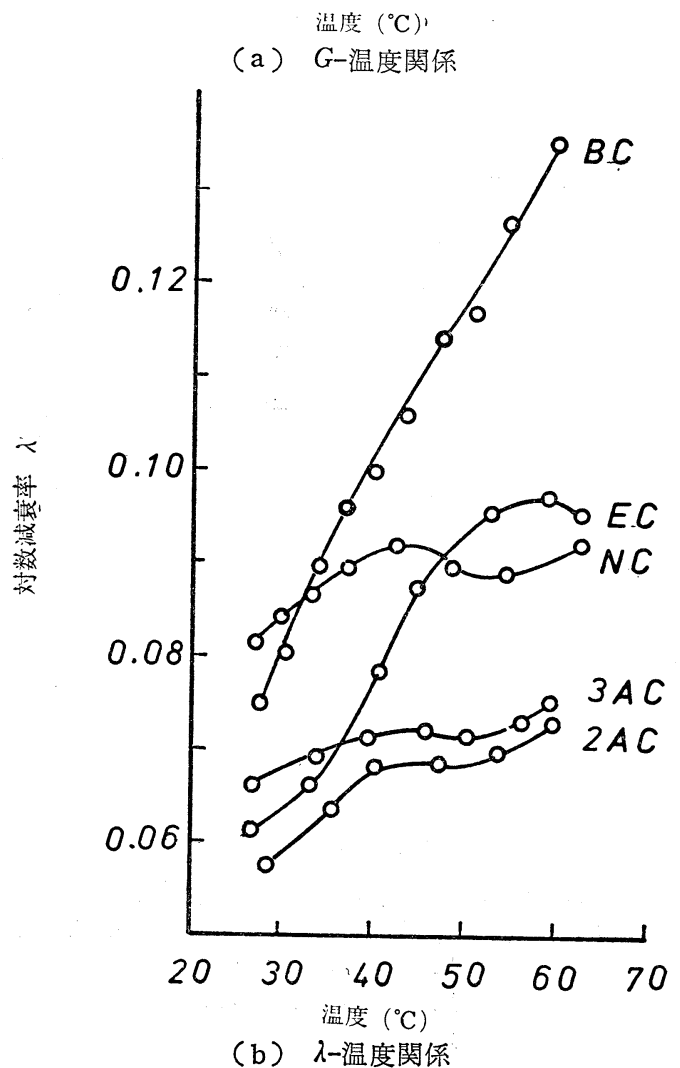

図-7 セルロース系塗膜のせん断弾性率 $G$ と対数減 衰率 $\lambda$ に及ぼす温度の影響

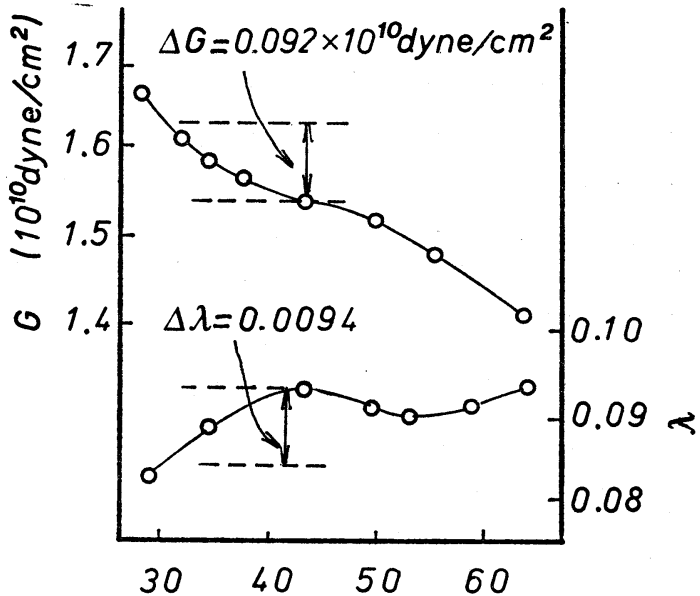

温度 $\left({ }^{\circ} \mathrm{C}\right)$

図-9 NC の粘弾性に及ぼす温度の影響

合が水分子によって解離して，分子の運動性が増すこと によるためと考えられている。

吸湿転移と温度転移の関係を，NC について詳細に検

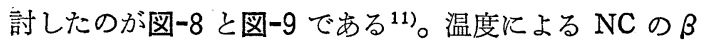
転移は $42^{\circ} \mathrm{C}$ に現われており，基準温度を $30^{\circ} \mathrm{C}$ にとっ

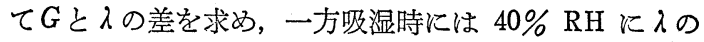
極大が現われるので， $0 \% \mathrm{RH}$ と $40 \% \mathrm{RH}$ のときのG と入の差を求めると表-2 のようになり，これでみると 温度効果よりも湿度効果の方が大きい。 


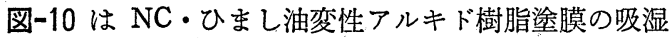
による粘弾性曲線の変化を示し ${ }^{11)}$, アルキド樹脂量が

表-2 ニトロセルロース塗膜の吸湿転移と温度転移

\begin{tabular}{|c|c|c|}
\hline 項 & \begin{tabular}{|l|} 
吸湿転移 (at $\left.30^{\circ} \mathrm{C}\right)$ \\
$0 \% \mathrm{RH} \longrightarrow 40 \% \mathrm{RH}$
\end{tabular} & $\begin{array}{c}\text { 温度転 移 } \\
30^{\circ} \mathrm{C} \longrightarrow 42^{\circ} \mathrm{C}\end{array}$ \\
\hline$\Delta G\left(\mathrm{dyn} / \mathrm{cm}^{2}\right)$ & $0.185 \times 10^{10}$ & $0.092 \times 10^{10}$ \\
\hline$\Delta \lambda$ & 0.013 & 0.0094 \\
\hline
\end{tabular}

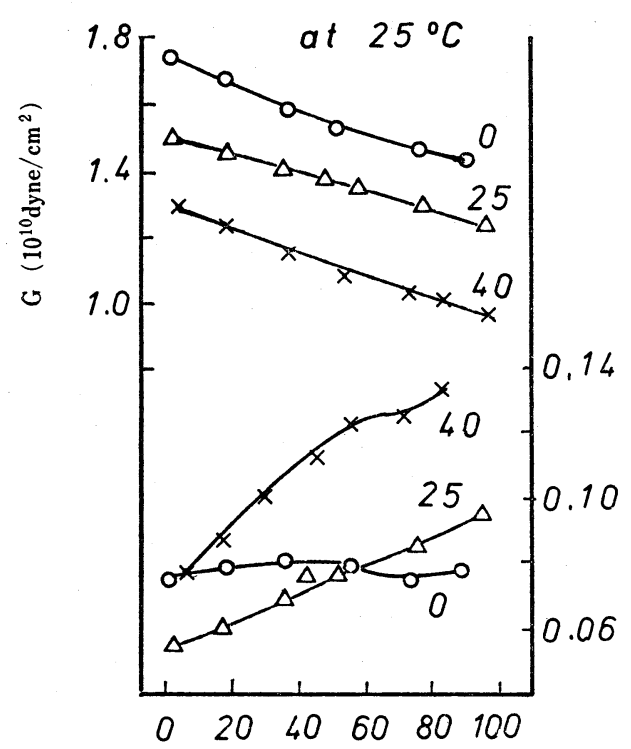

相対湿度 $(\%)$

図-10 NC・アルキド樹脂塗膜の粘弾性曲線に 及ぼす湿度の影響

困中の数字はアルキド樹脂量（wt\%）を表わす。
$25 \mathrm{wt} \%$ 以上になると, 湿度感受性が大きくなる。通常, NCラッカーのバインダー組成はアルキド樹脂を $40 \mathrm{wt} \%$ 以上含有しているから, 実用条件下にある NC ラッカー 塗膜の物性は湿度によってかなり大きな影響を受けると 考えられる。

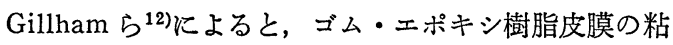
弾性は吸湿による水の可塑化作用によりエポキシ樹脂の $T_{g}$ が低下し, 同時に低温領域に水による転移（water transition）が現われるといら。皮膜を再乾燥すると， 粘弾性曲線はもとの状態にもどる。このような吸湿によ り誘起される転移は, ポリマーの化学構造に依存して いる。

図-11 は熱硬化性アクリル塗膜を $63^{\circ} \mathrm{C} て ゙ 75 \% \mathrm{RH}$ と $100 \% \mathrm{RH}$ の条件のもとでクリープ試験したときの結 果である。同じ試料の絶乾状態に括けるクリープ曲線も 併記した。この図をみると, 湿度は温度と同じようにク

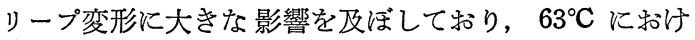
る $75 \% \mathrm{RH}$ と $100 \% \mathrm{RH}$ のクリープ挙動は $0 \% \mathrm{RH}$ の $67^{\circ} \mathrm{C}$ と $74^{\circ} \mathrm{C}$ のクリープ挙動にほぼ相当する。これ はクリープの遅延変形機構に叔いて, 塗膜中への水分子 の収着が温度による可塑化と同じ効果を有することを示 している。

上述のように粘弾性挙動に対して, 湿度変化が温度変 化と同じ効果をもたらすとすれば，湿度-時間換算則が 成立すると考えられる。図-12 はポリ酢酸ビニルの温度 を変えた応力緩和実験から求めた master relaxation curve と, 湿度を变えた応力緩和実験から求めた master

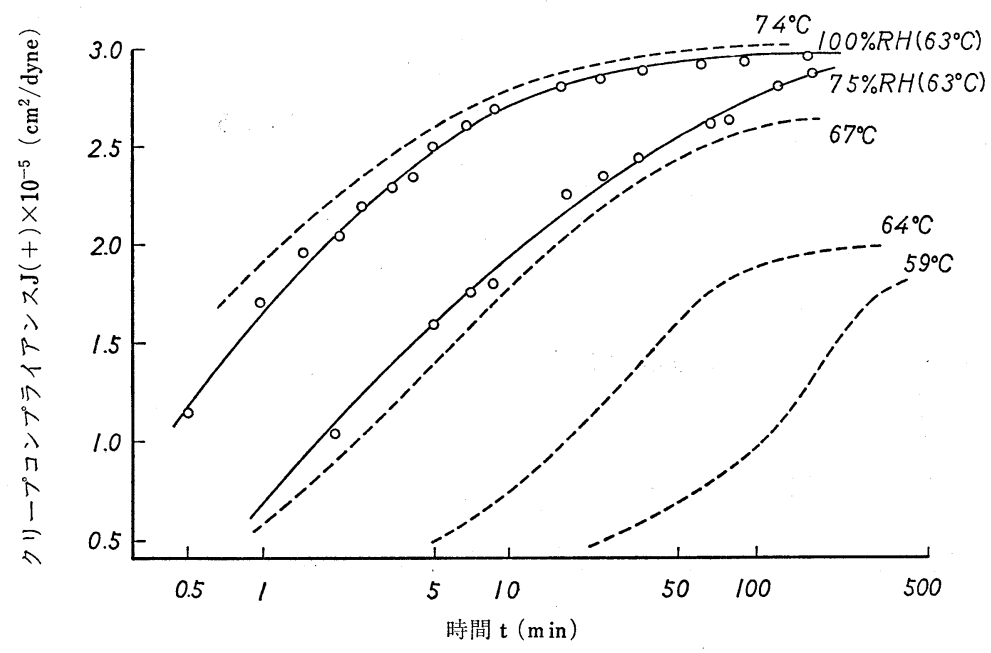

図-11 熱硬化性アクリル塗膜のクリープ曲線に及ぼす温度と湿度の影響 (鎖線は絶乾状態の試料の挙動を示す) 


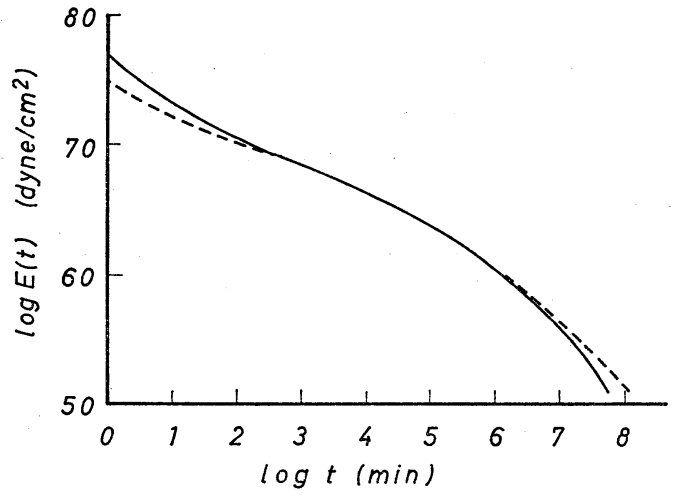

図-12 ポリ酢酸ビニルの $40^{\circ} \mathrm{C}, 0 \% \mathrm{RH}$ に打る master relaxation curve.

実線：湿度を変えた実験から求めたもの 破線 : 温度を变えた実験から求めたもの

relaxation curve を示し ${ }^{5)}, t<10^{2} \mathrm{~min}$ と $t>10^{7} \mathrm{~min}$ の領域を除くと，この二つの曲線はきわめてよく一致す ることが認められ，このことは湿度-時間換算則が成立 することを示している。

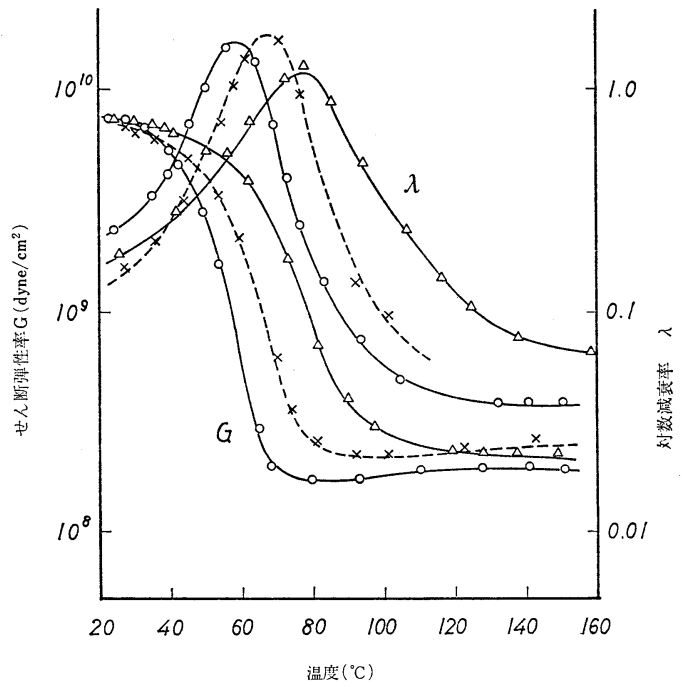

図-13 アクリル・メラミン樹脂塗膜の沸水特よび 加熱処理による粘弾性曲線の変化

\section{4. 熱水処理による塗膜の力学的性質の変化}

\section{1 熱水処理による塗膜の粘弾性変化}

図-13 はアクリル・メラミン樹脂塗膜の沸騰水就よび 加熱処理による粘弾性曲線の变化を示す。沸水処理によ り入曲線は高温側に移動してブロードになり，ガラス転 移温度 $T_{g}$ とゴム状弾性率 $G_{r}$ が大きくなる。沸水処理 時に末反応メラミン樹脂や低分子量プレポリマーが溶出 するために可塑化効果が低下して $T_{g}$ の上昇として現わ れ, 同時に溶出に伴ら void の発生により塗膜構造が不 均一になり，入曲線はブロードになる。このケースでは 沸水処理による分子鎖の切断はないようで, $G_{r}$ の変化 からみると橋かけ間分子量 $M_{c}$ は変化しないよらに考え られる。熱処理の場合も $\lambda$ 曲線は高温側に平行移動し, $T_{g}$ と $G_{r}$ が大きくなる。しかし, 沸水処理と熱処理を 比較すると, 前者の変化の方がはるかに大きく, 塗膜劣 化に及ぼす水の影響の大きいことを示している。

\section{2 熱水処理過程における弾性率の変化}

塗膜の劣化は塗膜分子の分解反応とみることができ, その際には分子鎖や橋かけ点の切断を伴らから，劣化に より塗膜の弾性率は低下するはずである。したがって, 塗膜の弾性率の経時的変化を追跡することによって, 劣 化挙動を調べることができる。

Flory の理論によると，膨潤平衡時のゴム状領域にあ るポリマーの $M_{c}$ は次の式から求めることができる ${ }^{13)} 。$

$$
f=\frac{\rho R T}{M_{c}} \cdot\left(1-\frac{2 M_{c}}{M}\right) \cdot\left(\varepsilon-\frac{1}{\varepsilon^{2}}\right) \cdot v_{r}^{-\frac{1}{3}}
$$

ここで, $f$ は引張り応力, $R$ はガス定数, $T$ は絶対温度, $M$ は初期分子量, $\rho$ は密度, $\varepsilon$ は伸長比, $v_{r}$ は体積分率 である。

（1）式は複雑であるので，次のように仮定して簡易化 する。

(1) $M$ は $M_{c}$ にくらべて十分に大きいとして $(1-2$ $\left.M_{c} / M\right) \doteqdot 1$ とする。

(2) 通常沸水中の膨潤度は $10 \%$ 以下であり， $v_{r}$ は $1 / 3$ 乗できくので $v_{r} \doteqdot 1$ とする。

(3) $\rho$ は測定中不変として, $\rho R T=K$ と报く。

\begin{tabular}{|c|c|c|c|c|c|c|c|}
\hline \multirow{2}{*}{ 塗 } & \multirow{2}{*}{$\frac{\text { 焼付仔条件 }}{{ }^{\circ} \mathrm{C} \times \min }$} & \multicolumn{3}{|c|}{$T_{g} \quad\left({ }^{\circ} \mathrm{C}\right)$} & \multicolumn{3}{|c|}{$G_{140}\left(\mathrm{dyn} / \mathrm{cm}^{2}\right)$} \\
\hline & & 処 理 前 & 沸水処理 & 熱 処 理 & 処 理 前 & 沸水処理 & 熱 処 理 \\
\hline アクリル・メラミン樹脂 & $140 \times 60$ & 62 & 76 & 68 & $1.9 \times 10^{8}$ & $2.2 \times 10^{8}$ & $2.3 \times 10^{8}$ \\
\hline
\end{tabular}


したがって，(1)式は次のようになる。

$$
\frac{f}{\varepsilon-\varepsilon^{-2}}=\frac{K}{M_{c}}
$$

ここで, $f / \varepsilon-\varepsilon^{-2}$ は弾性率である。塗膜を沸水処理する ときは, $K / M_{c}$ は処理時間 $t$ の函数であり, 次の式で表 わされる。

$$
\frac{K}{M_{c}}=E(t)
$$

$E(t)$ は $M_{c}$ と逆比例の関係があり， $M_{c}$ が大きいと小 さくなる。いま $E(t)$ を見かけの橋かけ密度とすると， この変化は劣化の尺度になる。一般に $E(t)$ はほほぼ指数 函数的に変化するので， $k$ を劣化速度定数とすると，次 の式で表わすことが可能である。

$$
\log \frac{E(t)}{E(0)}=-\frac{k_{1}}{2.3} t-\frac{k_{2}}{2.3} t
$$

ここで, $t$ は沸水処理時間, $E(0)$ は $t=0$ に拈ける見 かけの橋かけ密度, $E(t)$ は $t=t$ に郝見かけの橋か け密度である。

通常, 沸騰水の温度 $\left(98 \sim 99^{\circ} \mathrm{C}\right)$ は塗膜の $T_{g}$ より高 く, 分子の熱運動は活発で, 水の拡散が起こりやすく, 可塑化の効果は大きい。沸騰水に上る膨潤は 60 分以内 で平衡に達し, 平衡膨潤状態では水の可塑化効果の時間 的変化は, 弾性率の変化としては観測されない。したが って, 平衡膨潤状態で弾性率が低下するとすれば，それ は水の拡散によってバインダー分子の間隙が押しひろげ られて二次結合が解離し, 同時に加水分解によって一次 結合が切断するため之考学られる。

図-14 は熱硬化性アクリル塗膜の沸水処理による $\log$ $E(t) / E(0)$ の変化を示し, 表-3 は各試料の初期橋かけ 密度 $E(0)$ と劣化速度定数 $k$ の值を示す。アクリル・エ ポキシ樹脂塗膜は $E(0)$ の值も大きく, $k$ の值は小さく, 沸水処理に対する抵抗性は大きい。一方，自己架橋型の アクリル樹脂叙膜は $E(0)$ が小さく， $k$ の值は大きく， 橋かけ密度が低いだけでなく，水の浸透による可塑化効 果や二次結合の切断以外飞, バインダー分子鎖の切断が 生起していることを示唆している。また，アクリル・メ ラミン樹脂塗膜は $E(0)$ が大きく, 初期憍かけ密度は大 きいが，沸水処理中の挙動は特異である。すなわち，橋 か村密度の時間的变化は沸水処理 100 分を境として, コ

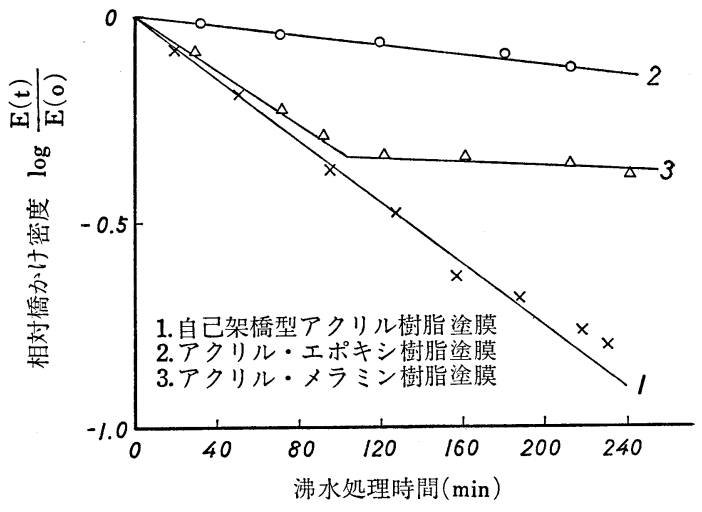

図-14 熱硬化性アクリル叙膜の沸水処理による相 対橋かけ密度の変化

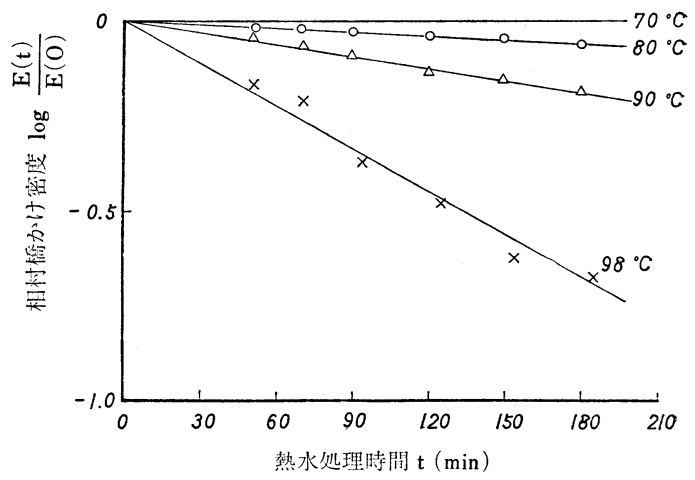

図-15 自己架橋型アクリル樹脂塗膜の $\log \frac{E(0)}{E(t)}-t$. 関 係に及ぼす熱水温度の影響

ウ配の異なる二つの直線からなっている。第一段階は塗 膜中への沸水の浸透と，それによる未反応メラミン樹脂 やプレポリマーの溶出と水の可塑化効果によるものであ る。第二段階では水の拡散過程と溶出成分との置換が終 り, 強固な橋かけ結合を有する樹脂が残り, バインダー 分子鎖の切断は生起しないことを示唆していると考兄ら れる。

図-15 は自己架橋型熱硬化性アクリル塗膜の熱水処理 に和沙る水の影響を示し, 水温の上昇とともに弾性率の 低下が著しくなり, 劣化速度の増大が認められる。この 塗膜の $T_{g}$ は $62^{\circ} \mathrm{C}$ (自由礼じり振動法で測定) であり,

表-3 熱硬化性アクリル塗膜の初期橋かけ密度 $E(0)$ と劣化速度定数 $k$

\begin{tabular}{c|cc|c|c|c|c}
\hline No. & \multicolumn{1}{|c|}{ 塗 } & 膜 & 焼 付 け 条 件 & $\begin{array}{c}E(0) \\
\left(\mathrm{g} / \mathrm{cm}^{3}\right)\end{array}$ & $\begin{array}{c}k_{1} \\
\left(\mathrm{~min}^{-1}\right)\end{array}$ & $\begin{array}{c}k_{2} \\
\left(\mathrm{~min}^{-1}\right)\end{array}$ \\
\hline 1 & 自己架橋型アクリル & $140^{\circ} \mathrm{C}, \quad 30 \mathrm{~min}$ & $1.55 \times 10^{3}$ & $8.53 \times 10^{-3}$ & - \\
2 & アクリル・エポキシ & $140^{\circ} \mathrm{C}, \quad 30 \mathrm{~min}$ & $5.08 \times 10^{3}$ & $1.15 \times 10^{-3}$ & - \\
3 & アクリル・メラミン & $140^{\circ} \mathrm{C}, \quad 60 \mathrm{~min}$ & $5.50 \times 10^{3}$ & $7.18 \times 10^{-3}$ & $0.40 \times 10^{-3}$ \\
\hline
\end{tabular}




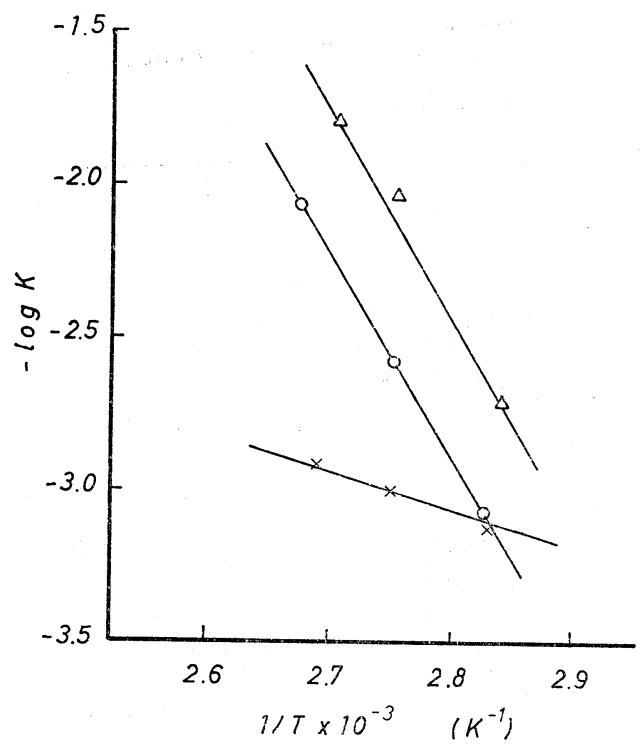

図-16 熱硬化性アクリル塗膜の $\log k-\frac{1}{T}$ 関倸

一○一：自己架橋型アクリル樹脂塗膜 （相対橋かけ密度测定より）

一 $\triangle$ 一 : 自己架橋型アクリル樹脂塗膜 (応力緩和測定より)

一メー:アクリル・エポキシ樹脂 $(9: 1)$ 塗膜 (応力緩和測定より)

熱水劣化はガラス転移後のゴム状領域で生起することが わかる。図-15 から $k$ を求め, $\log k$ と $1 / T$ の関係をプ ロットすると図-16のようになり，Arhennius の式(5) を用いて劣化の活性化エネルギーを求めると， 30.5 $\mathrm{kcal} / \mathrm{mol}$ となる。

$$
k=A e^{-E_{a} / R T}
$$

ここで， $E_{a}$ は見かけの活性化エネルギー，A は定数で める。

この $30.5 \mathrm{kcal} / \mathrm{mol}$ という値は天然ゴム ${ }^{14)}$ 和よびウレ タンゴム ${ }^{15)}$ の酸化切断の 活性化エネルギーとほぼ一致 し，バインダー分子鎖の切断が生起していると考えられ る。すなわち，塗膜はガラス転移後のゴム状領域で熱水 処理されると，熱水の塗膜中への拡散膨潤によって分子 鎖の切断が生起することを示唆している。

\section{3 熱水処理時の塗膜の応力緩和}

一般に固体ポリマーは粘弾性体であるから一定ひずみ を与えて保持した場合，応力は時間とともに緩和する。 伈力緩和は時間の函数であるとともに温度の影響も著し い。緩和曲線は経䮐的には Maxwell 型の単一指数曲線 で表わされるものが多いが，ウレタンゴムなどではいく つかの指数的減衰項で表現した方が実験事実に適合す
る。

多くの橋かけポリマーは網目中の結合鎖はすべて同じ 強さをもっているわけではないから，いくつかの緩和時 間による不連続分布で表わされる ${ }^{16)}$ 。

$$
\frac{f(t)}{f(0)}=A e^{-k_{1} t}+B e^{-k_{2} t}+C e^{-k_{3} t}+
$$

ここで, $f(0)$ と $f(t)$ は時間 $t=0$ 牰よび $t=t$ に打け る応力, $k_{i}$ は緩和速度定数で緩和時間 $\tau$ の逆数, $A, B$, $C, \cdots \cdots$ 洛緩和時間に相当する割合を表わし， $A+B+$ $C+\cdots \cdots=1$ である。（6）式の緩和定数は Tobolsky ら の解析法にもとづいて, 図上から求めることができる ${ }^{17) 。 ~}$ 熱水中に打ける塗膜の劣化状態を応力緩和実験で追跡 したものに，箱崎ら 18,19$)$ と小管ら ${ }^{20,21)}$ の研究があるの でそそれを紹介する。図-17 はアクリル・エポキシ樹脂 塗膜の沸水中と加熱空気中に拉ける応力緩和挙動を示 す ${ }^{18)}$ 。沸水中と加熱空気中では同じ温度でも, 緩和速度 に著しい差が認められる。エポキシ樹脂量 $0 \mathrm{wt} \%$ の塗 膜では, 沸水中の相対応力 $f(t) / f(0)$ は約 200 分でほぼ ゼロになるのに対して，加熱空気中では 200 分経過後で も $f(t) / f(0)=0.5$ であり, 緩和平衡になる傾向がみられ る。エポキシ樹脂で橋かけした塗膜の緩和挙動は全体的 にゆるやかであり，ふ九い気の影響にも同様な傾向が認 められる。沸水中と空気中では膨潤の有無の相違はある が, 沸水中では水の拡散による分子鎖の切断があり,一方 空気中では酸化劣化による分子鎖の切断が考劣られる。 加熱空気中の劣化速度は沸水中の劣化速度にくらべると 小さく, ポリマーの劣化に打ける水の影響は大きい。

図-18 はアクリル・エポキシ樹脂塗膜の応力緩和挙動 に及ぼすエポキシ樹脂量の影響を示す18)。エポキシ樹脂 量の多いほど相対応力が大きく, 緩和時間が長くなるの

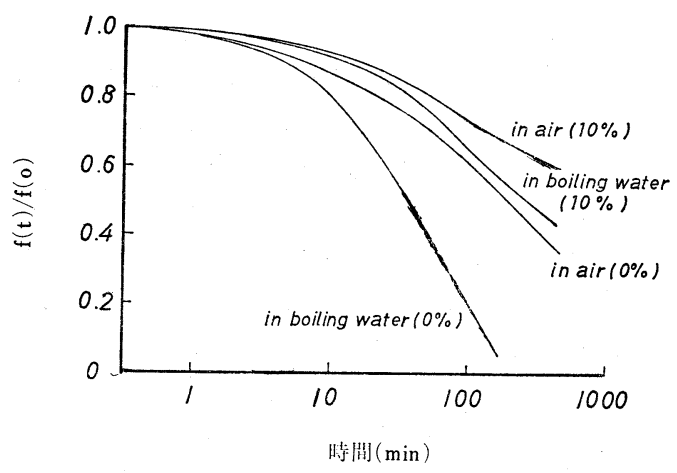

図-17 熱硬化性アクリル塗膜の応力緩和に及洔す ふん团気の影響

1. （）内の数字はエポキシ樹脂量 $(\mathrm{wt} \%)$ を 表わす

2. 沸水, 空気中とも $98^{\circ} \mathrm{C}$ 
は狳膜の橋かけ密度が増加するためである。この塗膜の 応力緩和定数は表-4 のようになる。エポキシ樹脂量 0 $\mathrm{wt} \%$ と $5 \mathrm{wt} \%$ の塗膜は一つの緩和速度定数 $\left(10^{-2}\right)$ で表わされるが, $10 \mathrm{wt} \%$ ブレンド塗膜では二つの速度 定数 $\left(10^{-2}\right.$ と $\left.10^{-3}\right), 20 \mathrm{wt} \%$ ブレンド塗膜では三つの 速度定数となり，その速度は次第に小さくなる。このよ うに，緩和時間がいくつにも分離されるのは，塗膜の網 目が強さの異なる結合から構成される不均一構造である ことを示唆している。また図-16 には応力緩和測定から 求めた $\log k$ 対 $1 / T$ 関係を併記したが，活性化エネルギ 一はエポキシ樹脂量が $0 \mathrm{wt} \%$ のときは $30.9 \mathrm{kcal} / \mathrm{mol}$ で橋かけ結合の切断が生起しているのに対して, エポキ シ樹脂量 $10 \mathrm{wt} \%$ の塗膜は $6 \mathrm{kcal} / \mathrm{mol}$ と小さく, 水素 結合のような二次結合の切断が生起すると考㝋られる。

図-19 はエポキシ・尿素樹脂塗膜の応力緩和曲線に及 ぼすふんい気の影響を示す20)。加熱空気中での測定は短 時間側で応力が急激に低下するのに対して，熱水中での 応力緩和は長時間側で応力の急激な低下が生じる。加熱 空気中では化学緩和は生起しないで物理緩和だけが起こ るのに対して，熱水中では初期緩和過程で分子鎖のセグ メント運動による物理緩和が起こり，後半の緩和過程で は網目鎖に対する水の化学的作用による分子鎖の切断な ぞの化学緩和の生起が 推定されている。表-5 は緩和実

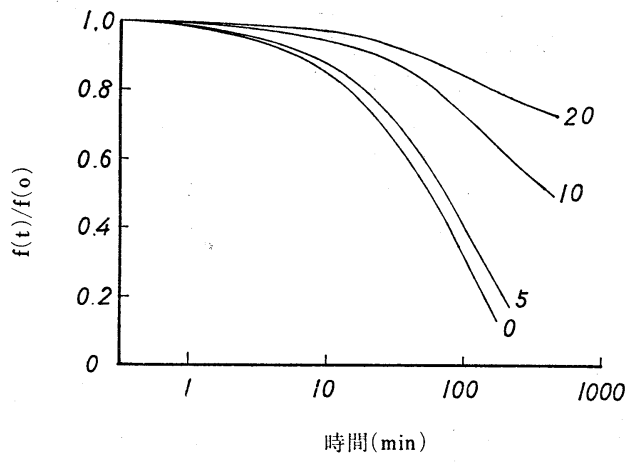

図-18 アクリル・エポキシ樹脂塗膜の沸水 $\left(98^{\circ} \mathrm{C}\right)$ 中における応力緩和曲線に及ぼすエポキシ樹 脂量の影響

（図中の数字はエポキシ樹脂量（wt\%）を表わす）

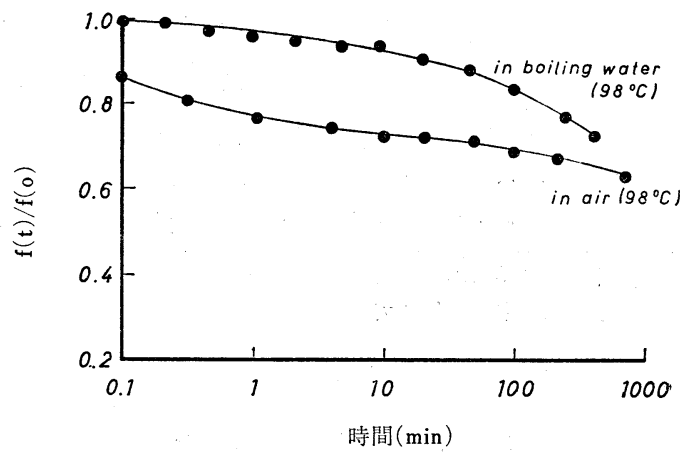

図-19 エポキシ・尿素樹脂塗膜の応力緩和曲線に 及ぼすふん囲気の影響

（尿素樹脂含有量 $20 \mathrm{wt} \%$ )

の $f(0)$ から求めたヤング率 $E(0)$ の值を示し, 空気中 にくらべると, 熱水中の $E(0)$ の值は小さく, 水分子に よる可塑化効果が確認される ${ }^{20)}$ 。

表-6 は 3 種類の塗膜の熱水中の最大緩和時間 $\tau_{m}$, 網 目密度 $n_{0}$ および活性化ェネルギー $E_{a}$ を示す20,21)。工 ポキシ・尿素樹脂塗膜の $n_{0}$ はアクリル・メラミン樹脂 塗膜 (溶剤型) より小さいが, $\tau_{m}$ が大きく, 3 種類の塗 膜の中では最も安定している。エポキシ・尿素樹脂塗膜 の橋かけ反応で生じたメチレン・エーテル結合は,アク リル・メラミン樹脂塗膜のメチレン・エステル結合より も加水分解を受けにくいと考えられる。また, アクリル・ メラミン樹脂では電着塗膜は溶剂型塗膜よりも $n_{0}, \tau_{m}$. が小さく,これは電着塗膜が溶剤型塗膜よりも耐水性の 劣ることを示している。この 3 種類の塗膜の熱水中での 活性化エネルギーは 25〜 $26 \mathrm{kcal} / \mathrm{mol}$ で，いずれの塗膜 も熱水中では水分子による橋かけ分子鎖の一次結合の切

表-5 エポキシ・尿素樹脂塗膜のゼロ時間に扣ける ヤング率 $\left(\right.$ at $\left.98^{\circ} \mathrm{C}\right)$

\begin{tabular}{c|c|c}
\hline \multirow{2}{*}{$\begin{array}{c}\text { 尿素樹 脂量 } \\
(\%)\end{array}$} & \multicolumn{2}{|c}{$\begin{array}{c}\text { ゼロ時間に护けるヤソグ率 } E(0) \\
\left(\mathrm{dyn} / \mathrm{cm}^{2}\right)\end{array}$} \\
\cline { 2 - 3 } & 空 気 中 & $98^{\circ} \mathrm{C}$ 水 中 \\
\hline 10 & $9.50 \times 10^{7}$ & $2.10 \times 10^{7}$ \\
20 & $4.47 \times 10^{7}$ & $4.31 \times 10^{7}$ \\
40 & $6.52 \times 10^{7}$ & $4.26 \times 10^{7}$ \\
\hline
\end{tabular}

表-4 アクリル・エポキシ樹脂塗膜のエポキシ樹脂量と応力緩和定数

\begin{tabular}{c|c|c|c|c|c|c|c|c|c}
\hline $\begin{array}{c}\text { エポキシ量 } \\
(\mathrm{wt} \%)\end{array}$ & $A$ & $\begin{array}{c}k_{1} \times 10^{2} \\
\left(\mathrm{~min}^{-1}\right)\end{array}$ & $\begin{array}{c}\tau_{1} \\
(\mathrm{~min})\end{array}$ & $B$ & $\begin{array}{c}k_{2} \times 10^{3} \\
\left(\mathrm{~min}^{-1}\right)\end{array}$ & $\begin{array}{c}\tau_{2} \\
(\mathrm{~min})\end{array}$ & $C$ & $\begin{array}{c}k_{3} \times 10^{3} \\
\left(\mathrm{~min}^{-1}\right)\end{array}$ & $\begin{array}{c}\tau_{3} \\
\left(\mathrm{~min}^{2}\right.\end{array}$ \\
\hline 0 & 1 & 1.63 & 61 & & & & & \\
5 & 1 & 1.44 & 69 & & & & & \\
10 & 0.284 & 1.22 & 82 & 0.708 & 1.18 & 848 & & & \\
20 & 0.180 & 1.18 & 88 & & & & & \\
& 0.023 & 8.82 & 11 & & & & 0.795 & 2.81 & 3,580
\end{tabular}


表-6 塗膜の熱水中における $\tau_{m}, n_{0}, E_{a}$

\begin{tabular}{|c|c|c|c|c|}
\hline 塗 & 硬 化 条 件 & $\begin{array}{c}\tau_{m} \\
(\mathrm{~min})\end{array}$ & $\begin{array}{c}n_{0} \times 10^{4} \\
(\mathrm{~mol} / \mathrm{ml})\end{array}$ & $\begin{array}{c}E_{0} \\
(\mathrm{kcal} / \mathrm{mol})\end{array}$ \\
\hline エポキシ・尿素樹脂（尿素樹脂 $20 \mathrm{wt} \%$ ） & $180^{\circ} \mathrm{C}, 10 \mathrm{~min}$ & $2,890^{1)}$ & 4. 75 & 25 \\
\hline アクリル・メラミン樹脂 （電 着 塗 膜） & $140^{\circ} \mathrm{C}, 60 \mathrm{~min}$ & $140^{2)}$ & 3.03 & 26 \\
\hline アクリル・メラミン樹脂 （溶剤型塗膜） & $140^{\circ} \mathrm{C}, 60 \mathrm{~min}$ & $222^{2)}$ & 5.64 & 26 \\
\hline
\end{tabular}

注 1） $98^{\circ} \mathrm{C}$ 水中にて

2) $90^{\circ} \mathrm{C}$ 水中にて

断が生起していると考えられる。

\section{5. 塗膜の内部応力と水}

塗液または溶融樹脂から剛体素地面上で塗膜が形成さ れるときには，塗膜と素地との収縮性の相違にもとつうく 内部応力が発生する ${ }^{22)}$ この内部応力は塗膜のはがれ, 割れ，そりなどの欠陥の発生に重大な影響を与えるだけ でなく, 塗膜が剛体素地からはく離した後でも, 塗膜の 内部構造に異方性を誘発しやすい, ${ }^{23)}$ 。

通常塗膜の形成は常湿下で行なわれるから, 内部応力 の発生に湿度は大きく影響するはずである。図-20 は木 材（ヒノキ）に塗布した尿素樹脂接着剂の硬化過程に抒 ける内部応力と対数減衰率の变化を示す ${ }^{24)}$ 。内部応力は 塗布後最初は負の值を示すが，その後徐々に正の方向に 変化し, 対数減衰率の極大点付近から急激に上昇して一 定值に達し，その後は，横ばいになる。塗布後一度内部 応力の值が負になるのは，木材素地に溶剤が浸透して塗 布表面側の膨潤により木材素地にそりを生じるためであ る。その後木材中に浸透した溶剤の蒸発に伴って木材素 地のそりは減少し，接着剂の硬化により皮膜がゴム状態 からガラス状態に転移する時点から, 内部応力の急激な 増加が始まる。高湿度で低湿度のとき注ど, 内部応力の 発生が早い。表-7 は椋代ら ${ }^{24)}$ が求めた木材用接着剂の 内部応力に及ぼす温度と湿度の影響を示し, 硬化時の温 度が高く, 湿度の低いほど内部応力は大きくなるが，同 時に温度よりも湿度の影響の方の大きいことが認められ る。

表-8 は塗料組成とその内部応力の関係を示し ${ }^{25)}$, 湿 度の増加により内部応力は減少し，その低下率は塗料の 種類により異なることが認められる。図-21 はエポキシ 樹脂塗膜の内部応力に対する湿度の影響を示す26)。湿度 が $0 \% \mathrm{RH}$ のときには内部応力は変化しないが，湿度が 高いほど内部応力の低下は大きくなり，98〜100\% RH では無応力の状態を越えて反対方向の応力が発生する。

吸湿によって低下した内部応力は脱湿によって再び回 復する。図-22 は湿度を下げたときの塗膜の内部応力の 変化を示し ${ }^{27)}$, 膜厚が薄いほど内部応力の増加は大き

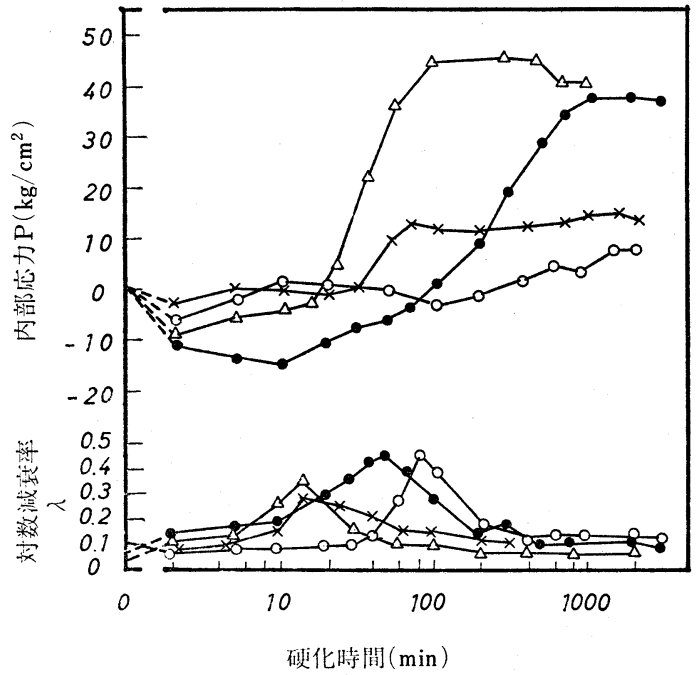

図-20 木片試料の両面に尿素樹脂系接着剤を塗布 したときの接着剤層の内部応力と対数減衰率 の硬化時間による変化

$\begin{array}{ccc}\text { 記号 } & \text { 温度 }{ }^{\circ} \mathrm{C} & \text { 湿度\% } \\ -0 & 30 & 33 \\ -\bigcirc- & 30 & 75 \\ -\triangle- & 50 & 38 \\ -\times- & 50 & 78\end{array}$

表-7 内部応力に及ぼす硬化温度と硬化湿度の影響

\begin{tabular}{c|c|c|c|c}
\hline 接 着 剤 & $\frac{\sigma_{L 50}}{\sigma_{L 30}}$ & $\frac{\sigma_{H 50}}{\sigma_{H 30}}$ & $\frac{\sigma_{L 30}}{\sigma_{H 30}}$ & $\frac{\sigma_{L 50}}{\sigma_{H 50}}$ \\
\hline 尿 素 樹 脂 & 1.07 & 1.67 & 5.00 & 3.19 \\
フェノール樹脂 & 1.46 & 1.79 & 3.43 & 2.80 \\
$\begin{array}{l}\text { レゾルシノール } \\
\text { 樹脂 } \\
\text { ポリ酢酸ビニル } \\
\text { エマルション }\end{array}$ & 1.69 & 2.41 & 5.22 & 3.67 \\
\hline
\end{tabular}

$\sigma_{L 50}, \sigma_{H 50}:$ それぞれ $50^{\circ} \mathrm{C}, 38 \% \mathrm{RH}$ および $50^{\circ} \mathrm{C}$, $78 \% \mathrm{RH}$ で $2,000 \mathrm{~min}$ 硬化した接着剤 層内の内部応力

$\sigma_{L 30}, \sigma_{H 30}:$ それぞれ $30^{\circ} \mathrm{C}, 33 \% \mathrm{RH}$ 䶻よび $30^{\circ} \mathrm{C}$, $75 \% \mathrm{RH}$ で $2,000 \mathrm{~min}$ 硬化した接着剤 層内の内部応力

い。Crol1 ${ }^{28)}$ も塗膜の内部応力に及ぼす湿度の影響は， 膜厚の薄い領域で大きいことを認めている。図-23 は土 
表-8 塗料組成と塗膜の内部応力 (at $60^{\circ} \mathrm{C}$ )

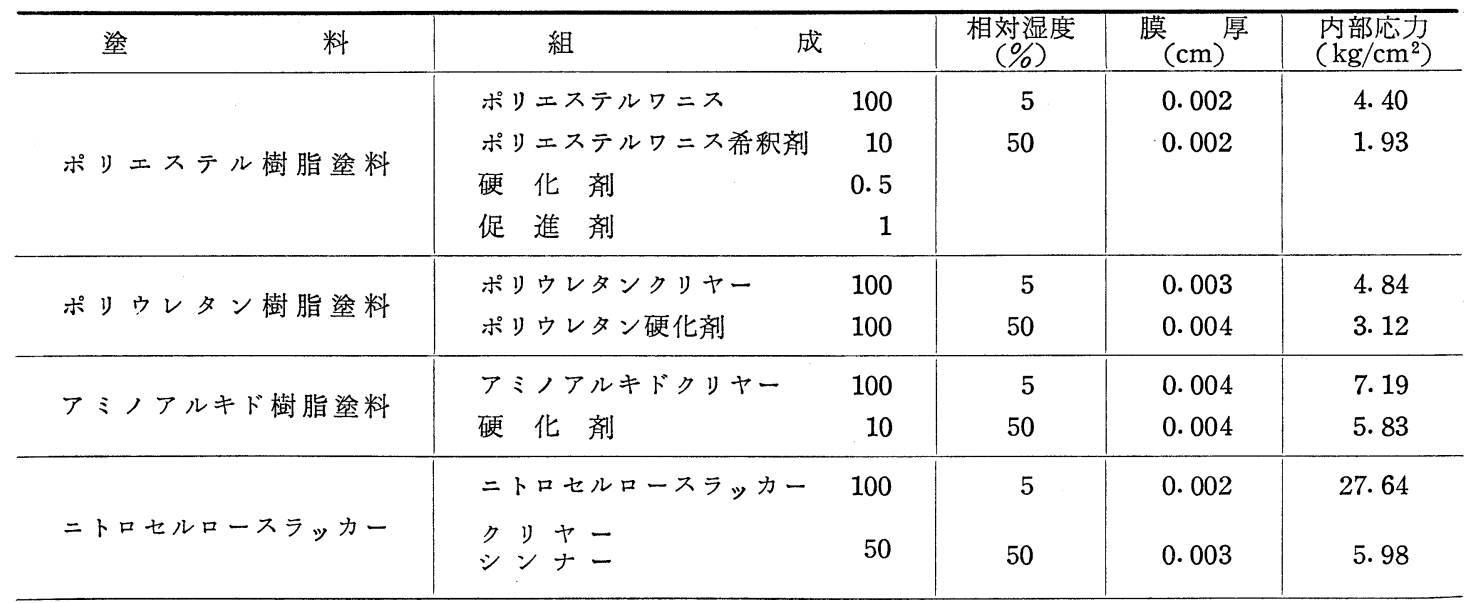

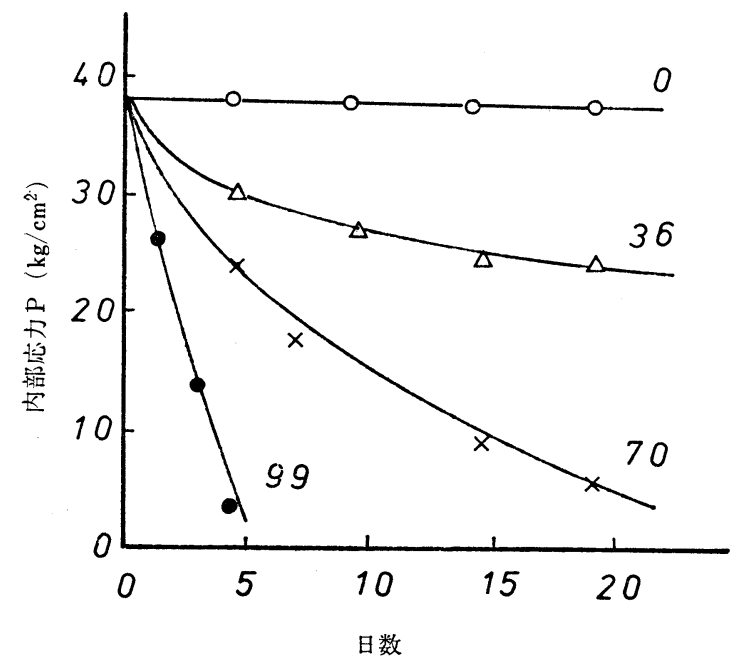

図-21 エポキシ樹脂塗膜の内部応力に及ぼす 湿度の影響

（図中の数字は相対湿度\%RH を表わす）

ポキシ樹脂塗膜の吸・脱湿過程における内部応力の変化 を示す29)。乾燥時に正の值を示していた内部応力が，吸 湿後負の值になるのは吸湿により塗膜が膨脹するためで ある。脱湿により内部応力の值は回復するが，もとの值 飞はもどらない。これは吸湿膨脹時に水素結合などの二 次結合が切断すると，脱湿時には分子鎖セグメントがそ の位置で安定化するためと考えられる。

塗膜の吸湿は温度上昇に伴ら熱膨脹にも影響を及ぼ す。図-24 はアルキド・メラミン樹脂塗膜の熱膨脹曲線 を示す ${ }^{30)}$ 。この測定は常温・常湿 $\left(20^{\circ} \mathrm{C}, 60 \sim 65 \% \mathrm{RH}\right)$ から開始しているので，温度上昇による熱膨脹曲線は最 初減少し，極小を経て増加する。最初の収縮は脱湿の影

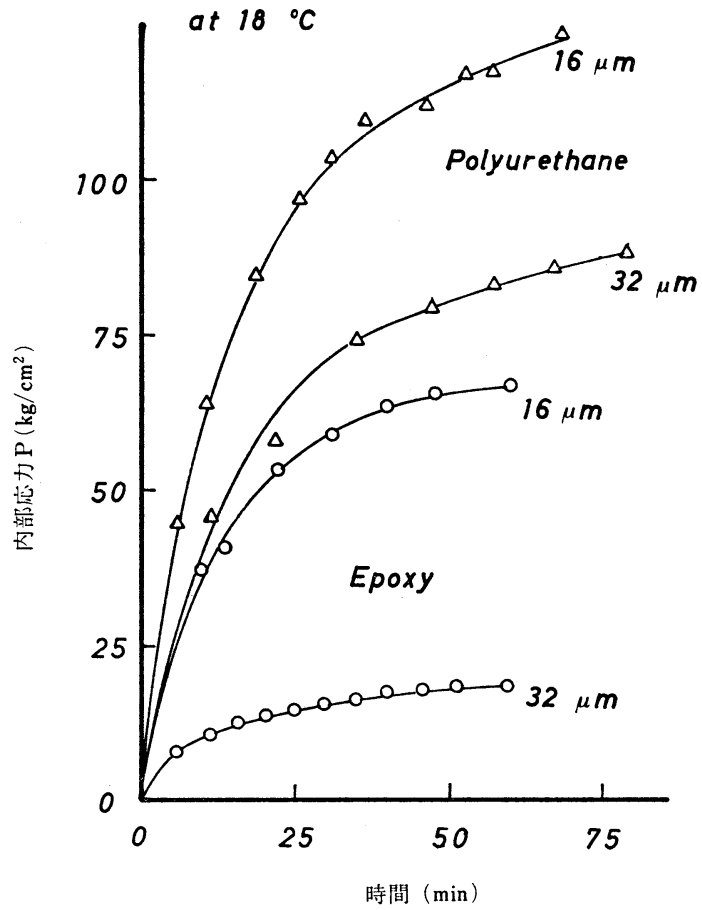

図-22 湿度低下により発生した塗膜の内部応力 $(55 \% \mathrm{RH} \rightarrow 15 \% \mathrm{RH})$

響によるもので, 温度差で $20^{\circ} \mathrm{C}$, 湿度で $10 \% \mathrm{RH}$ 以下 になると脱湿はほぼ完了し, 熱膨脹曲線は直線的に増大 する。熱硬化性塗膜の内部応力は $T_{g}$ 以下のガラス状態 に拈ける熱ひずみ $\varepsilon_{T}$ によるるので図 -24 の $\mathrm{PQ}$ に相当 するが，吸湿により $O Q$ だけ緩和されるので，観測され る見かけの内部ひずみ $を$ は OP になる。したがって， $\mathrm{OQ}$ は吸湿による緩和ひずみ $\varepsilon_{H}$ であり, 図-25 はアル キド・メラミン樹脂塗膜の $\varepsilon_{H}$ と顔料濃度の関係であ 


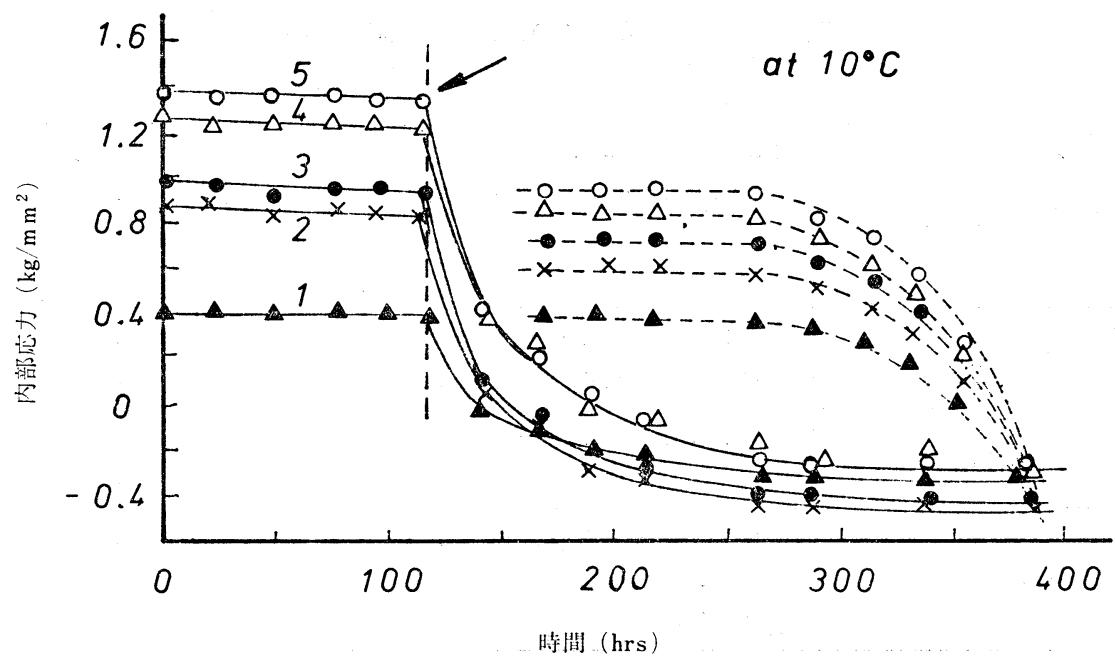

図-23 エピコート 1004 塗膜の吸・脱湿による内部応力の变化

注 1) 実線は吸湿過程, 点線は脱湿過程を示す。

2) 図中の数字は樹脂 $100 \mathrm{~g}$ に対する硬化剤添加量（g）を示す。

3）】印は $100 \% \mathrm{RH}$ の humidity box に入れたことを示す。

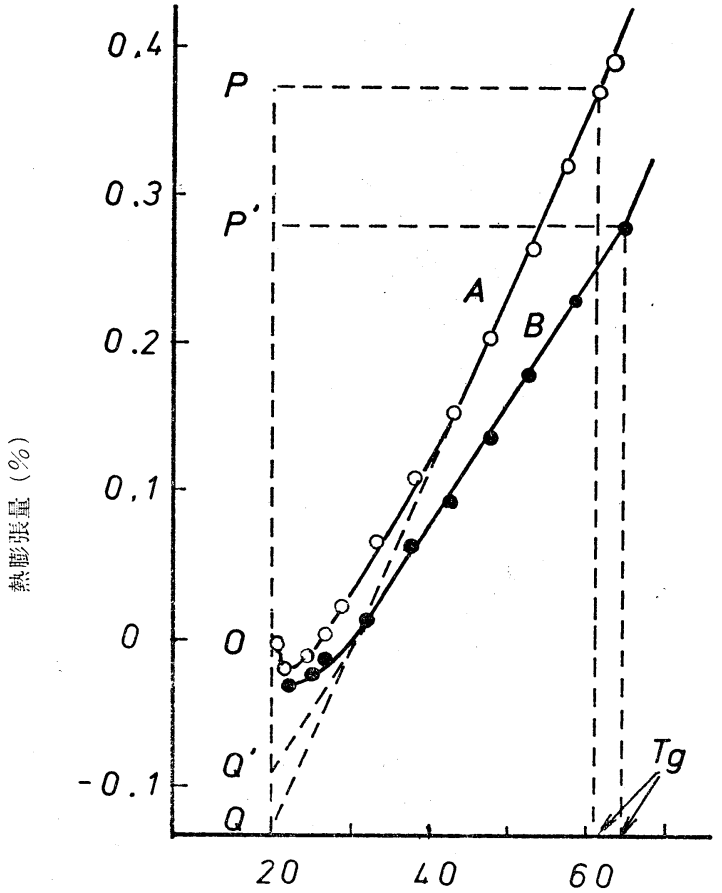

温度 $\left({ }^{\circ} \mathrm{C}\right)$

図-24 アルキド・メラミン樹脂塗膜の熱膨張曲線
$\mathrm{A}:$ : リヤー塗膜
$\mathrm{B}: \mathrm{TiO}_{2}(15 \mathrm{vol} \%)$ 含有塗膜

る ${ }^{30)} 。 \varepsilon_{H}$ は顔料濃度の増加とともに小さくなり, 特に タルクやグラファイトのような偏平粒子の添加は, 低顔

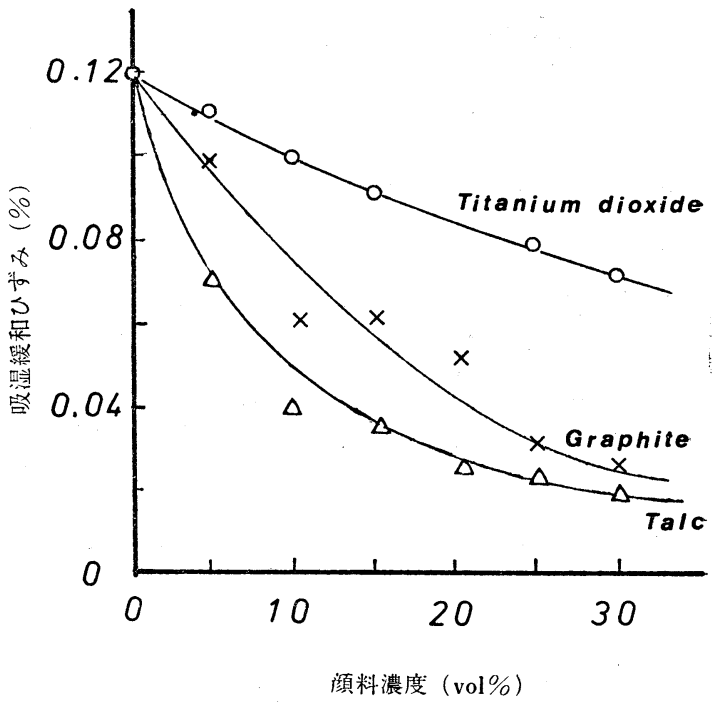

図-25 アルキド・メラミン樹脂塗膜の吸湿緩和ひ ずみに及ぼす顔料の影響

料濃度でも $\varepsilon_{H}$ の減少が大きい。フェノール樹脂・ポリ ビニルブチラール (PVB) 塗膜の熱膨脹でも同様な現象 が認められている ${ }^{311} 。$

$\varepsilon$ は $\varepsilon_{T}$ から $\varepsilon_{H}$ を差し引いた值として, 次のように なる。

$$
\varepsilon=\varepsilon_{T}-\varepsilon_{H}=\Delta \alpha \cdot \Delta t-\varepsilon_{H}
$$

ここで, $\Delta \alpha$ は塗膜と素地との線膨脹係数の差, $\Delta t$ は $T_{g}$ と測定温度の差である。図-26 はアルキド・メラミ ン樹脂の 顔料添加塗膜 ${ }^{30)}$, 図-27 はフェノール樹脂・ 


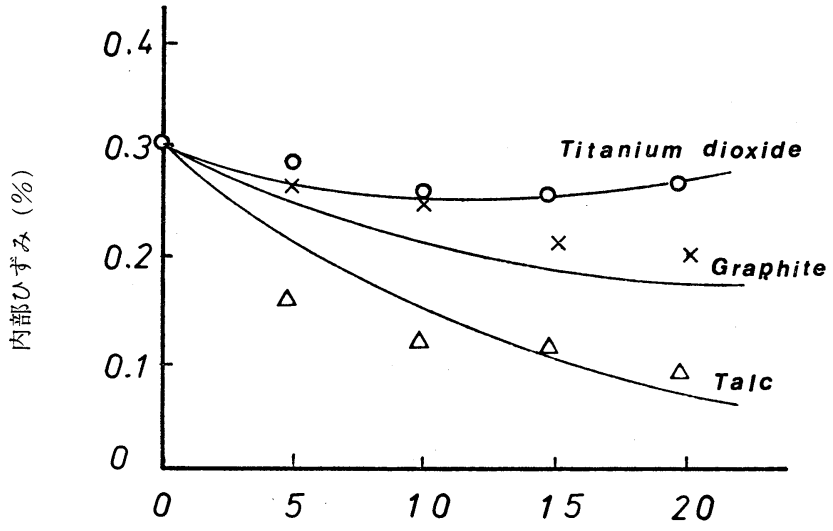

顔料濃度（vol\%）

図-26内部ひずみの実測值と計算值の対比 (1)

1. 試料：アルキド・メラミン樹脂系塗膜

2. 実線は計算值で， $\bigcirc, \triangle ， \times$ 印は実測值を示す。

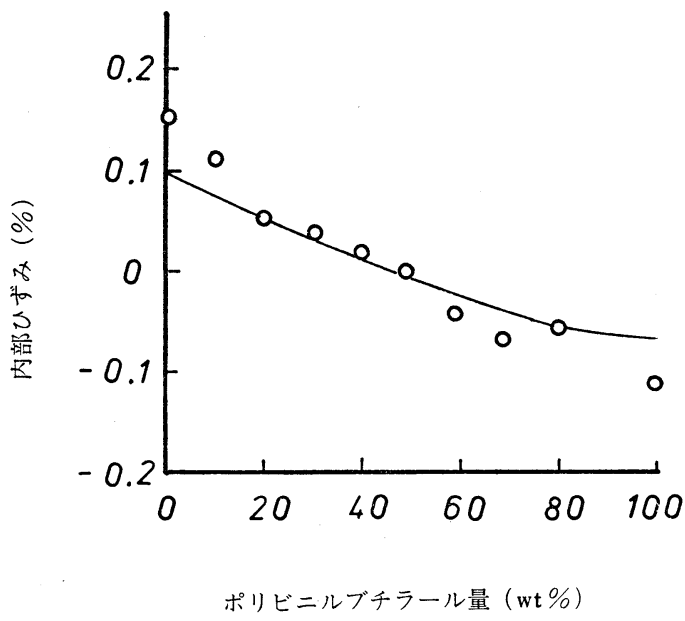

図-27 内部ひずみの実测值と計算値の対比 (2)

注 1) 試料：フェノール樹脂・ポリビニルブ チラール系塗膜

2）実線は計算值を，○印は実測值を示す。

PVB 塗膜 ${ }^{31)}$ の (7) 式による計算値と実測值の関係を対 比したもので, 両者はよく合致している。

図-28 はガラス板叙装膜を水中に浸セキしたときの内 部ひずみの変化を示す ${ }^{32)}$ 。 NC ラッカー, ポリエステル 樹脂扣よびポリウレタン樹脂塗膜では短時間の吸水によ り塗膜の収縮ひずみを打消して，塗膜内に無ひずみ状態 になり，その後の吸水によって $0.5 \%$ 以下のごく小さい 膨潤ひずみを生じる。これに対して，アミノアルキド樹 脂塗膜は吸水初期から大きい膨潤ひずみを示し，約 $3 \%$ に達する。
佐藤ら ${ }^{33)}$ は鋼板にエポキシ樹脂クリヤーを塗 装した試験片を水中に浸セキしてその付着性を 評価し，付着性と塗膜の物性値との関連性につ いて検討している。その結果によるこエエポキ シ樹脂塗膜の湿潤付着性は吸水膨潤応力之関係 があり，吸水膨潤による発生応力が小さく，応 力緩和性の大きい塗膜ほど湿润時の付着性が良 いといら。

\section{6. あとがき}

水は塗膜の形成から劣化に至る過程を通して 密接な関係があり, 塗膜の性能に大きな影響を 与えている。ここではクリヤ一塗膜の物性に及 ぼす水の影響についてまとめてみたが，顔料添 加塗膜の物性に及ぼす水の影響については, 前 に本誌 34,35 亿記述しているので割愛した。また 水は塗膜の付着性にも大きな影響を及汸してい るが，それについては拙著 ${ }^{36)}$ を参照願いたい。

$$
\text { 文献 }
$$

1）佐藤弘三 : “塗装の事典”, p. 230, 朝倉書店 (1980)

2）今井丈夫 : 表面, 15, 696 (1977)

3）今并丈夫：色材, 53, 713 (1980)

4) H.Fujita, A. Kishimoto: J. Polym. Sci., 28, 547 (1958)

5）藤田 博：材料試験， 7, 126 (1958)

6) G. Phillips : I. Oil Colour Chem. Assoc., 44, 575 (1961)

7) H. Williams : J. Oil Colour Chem. Assoc., 44, 713 (1961)

8）小管詔雄 : 塗装工学, $14[1], 4$ (1979)

9）佐藤弘三: “概説塗料物性工学”, p. 177, 理工出 版社 (1973)

10）藤本輝雄, 井上幸彦：高分子化学, 17，436 (1960)

11）井上幸彦, 藤本輝雄 : 色材， 33，302（1960）

12) M. B. Roller. J. K. Gillham : J. Coat. Technol., 50 [636], 57 (1978)

13) P.J.Flory : J. Chem. Phys., 18, 108 (1950)

14) A. V. Tobolsky, I. B. Prettyman, J.H. Dillon : J. Appl. Phys., 15, 324 (1944)

15) A. V. Tobolsky, V. Johnson, W. J. Mac Knight: J. Phys. Chem., 69, 476 (1965)

16）村上謙吉編：“高分子の化学レオロジー”，朝倉書 店 (1965)

17) A. V. Tobolsky, K. Murakami : J. Polym. Sci, 40, 443 (1959)

18）箱崎順一, 橋本 哲, 東村栄之助：材料, 16, 484 (1967)

19）箱崎順一, 橋本 哲, 東村栄之助：材料，16, 487 (1967)

20）小管詔雄，津川俊一：高分子論文集， $32 ， 252$ 


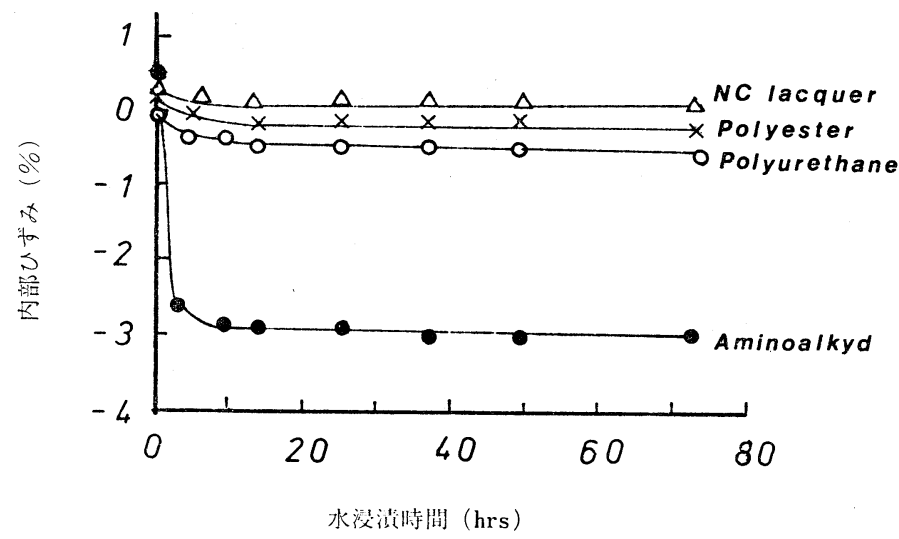

図-28 ガラス板塗装膜の水浸漬時における内部ひずみの变化

(1975)

21）小管詔雄：高分子論文集，35，131（1978）

22）佐藤弘三：“塗膜の付着”, p. 49, 理工出版社 (1981)

23）藤本辉雄, 半上幸彦, 小皇陽之助：工化，63，851 (1960)

24）椋代純輔, 暒田 熙, 矢田茂樹：日本接着協会誌, 9, 58 (1973)

25）福山万次郎：材料, 18, 851 (1969)

26) S. A. Shriener, T.A. Volkova, A.S. Arvan : Lakokras. Mater. Primen., [5], 32 (1968)

27) J. L. Prosser : Mod. Paint Coat., 67 [7], 47 (1977)

28) S.G.Croll : J. Coat. Technol., 51 [659], 49
(1979)

29）佐藤弘三，井上幸彦：色材，32，349（1959）

30）井上幸彦，小泉陽之助，佐藤弘三：工化， 61, 1350 (1958)

31）佐藤弘三，井上幸彦：色材，31，337（1958）

32）中戸莞二, 白石信夫, 梶田 熙: 木材学会誌, 9, 6, 225 (1963)

33）佐藤忠明, 中谷栄作, 木暮英雄 : 色材, 54, 333 (1981)

34）佐藤弘三 : 色材, 46, 261 (1973)

35）佐藤弘三 : 色材, 54, 490 (1981)

36）佐藤弘三: “塗膜の付着”, p. 169, 理工出版社 (1981)

\section{協替関係}

第 8 回腐食防食工学入門講習会

主催 (社) 腐食防食協会

協賛 (社)色材協会 他

日 時 昭和 57 年 7 月 21 日(水), 22 日(木), 23 日 (金) $9: 30 \sim 16: 30$

会場 オームゼミナール（東京都千代田区神田錦町

プログラム 3-1 (株)オーム社内 Tel. 03 (233) 0641)

7 月 21 日（水）

1. 腐食と防食技術（東京理科大 岡本 剛）

2. 腐食の原理

- 形態からみた各種の腐食とそのメカニズム（東大生 研 增子 昇)

-機械的因子を持つ各種の腐食（大阪府立大工 山川 宏之)

3. 防食の理論と方法（日本防食工業 小林豊治） 7 月 22 日 (木)

4. 特定環境に和引る腐食

- 高温腐食（日本治金工業 根本力男）
- 露点腐食 (住友金属工業 長野博二)

-大気, 海水, 淡水腐食 (川崎製鉄 久野忠)

5. 耐食材料の特長と使い方

・ステンレス系耐食材（日本治金工業 遧沢浩一郎）

7 月 23 日 (金)

- 非鉄系耐食材（古河電気工業 小泉達也）

6. 防食技術の実際

・設備装置の設計に打ける防食技術の実際（東洋ェン ジニアリング工業 篠原孝順)

- 化学工場に和汓る防食技術の実際（味の素 鈴木紹 夫)

7. 腐食診断法（日本鋼管 松島 厳）

参加費 会員打上び協賛学協会会員 25,000 円, 非会員 35,000 円, 学生会員 5,000 円

申込締切 昭和 57 年 7 月 16 日までに申込んだ方にはテ キストを前送します。定員 50 名

申込先 (社) 腐食防食協会 (東京都千代田区神田神保町 2-23 $\bar{T}$ 101) Tel. 03 (261) 3275

$\overline{48[6]}$ 